\title{
James Norman Hall: Past, Present, and Future
}

\author{
ROBERT ROULSTON
}

James Norman Hall has been a rare and perhaps unparalleled phenomenon in American literature. For the last two decades of his life, the Iowa-born author ${ }^{1}$ was one of the best-known writers in the English-speaking world. Not only did the romances he wrote with Charles Nordhoff sell well: so did his solo achievements as a novelist. Moreover, for more than three decades he was a steady contributor to a respected journal, the Atlantic, and a frequent one to the Atlantic's peer and rival, Harper's. No mere popular entertainer, he wrote in virtually every genre, was never less than a skilled craftsman, and often dealt with important subjects in an effective manner. Although his popularity has declined since his death in 1951, the Bounty trilogy has remained constantly in print, usually in competing editions, and other books of his, both fiction and nonfiction, have been readily available. In the 1960s, furthermore, he and Nordhoff were the subjects of a dual biography by Paul L. Briand, Jr., and Hall himself was the focal point of Leland Johnson's The American Heritage of James Norman Hall. ${ }^{2}$ One would suppose, therefore, that so visible and prolific an author who has been accorded respect by the few people who have commented upon his works in print would have received substantial attention from scholars. The truth has been otherwise. Literary historians have ignored him. Academic journals, which in recent years have often found space for articles on far more obscure and less literate figures, have taken little cognizance of him. He has not fared much better in scholarly books surveying literature about the subject

- From a forthcoming Twayne United States Authors book.

1 Hall was born in Colfax, Iowa, on April 22, 1887.

2 Paul L. Briand, Jr., In Search of Paradise: The Nordhoff-Hall Story (New York: Duell, Sloane, 1966), and Robert Leland Johnson, The American Heritage of James Norman Hall: The Woodshed Poet and Co-Author of Mutiny on the Bounty (Philadelphia: Dorrance, 1969). 
with which Hall's name is most frequently associated-the South $\mathrm{Pa}$ cific. $^{3}$

Hall's writings, especially those he wrote without Nordhoff, deserve more attention. This is not to say that the adventure tales he and Nordhoff created together are devoid of merit. The adroit blending of myth and solid historical reality in Mutiny on the Bounty and the moral intensity of The Hurricane more than counterbalance their over-reliance upon plot contrivances and their tendency toward melodrama. And even some of the less impressive achievements of the famous team such as the two sequels to Mutiny on the Bounty (Men Against the Sea and Pitcairn's Island), No More Gas, and Botany Bay have enough felicities to make them seldom less than engrossing and sometimes a good deal more than that. But the collaborative nature of all these works as well as their plot-dominated structures resulted in an impersonality similar to that of Hollywood screenplays in the 1930s. Hall, to be sure, often injected his own attitudes and even some of his personal experiences into these books. But the contributions of Nordhoff-a man more saturnine in temperament and more matter-of-fact in his approach to writing--inevitably diluted Hall's efforts as did the imperatives of the genre.

The cogent ideas, the distinctive authorial voice, and the engaging personality of Hall emerge most compellingly in the selections he wrote without a partner. These include two novels (Lost Island and The Far Lands), a framework tale set in the late eighteenth century (Doctor Dogbody's Leg), three semiautobiographical war books (Kitchener's Mob, High Adventure, and Flying With Chaucer), an autobiography (My Island Home), a children's book (Mother Goose Land), an account of his trip to Pitcairn (The Tale of a Shipureck), four volumes of verse (The Friends; Oh, Millersville!; A Word for His Sponsor; and Her Daddy's Best Ice Cream), and dozens of sketches and essays, most of the best of which were reprinted in On the Stream of Travel, Mid-Pacific, Under a Thatched Roof, or The Forgotten One and Other True Tales of the South Seas.

The foregoing catalogue should make it apparent that, although he resided in Tahiti for three decades and is best known for his works set in the South Seas, Hall addressed himself to a variety of subjects,

3 Murray D. Welch in "James Norman Hall: Poet and Philosopher," South Atlantic Quarterly, 29 (April 1940):140-50, contends, as does the author of this study, that Hall is at his best as an essayist. There are cursory references to Hall in Jean Simon's La Polynésie dans l'art et la litterature de l'Occident (Paris: Boivin, 1939); James Baird's Ishmael: A Study of the Symbolic Mode in Primitivism (Baltimore: Johns Hopkins University Press, 1956); and Douglas L. Oliver's The Pacific Islands (New York: Doubleday, 1961). 
his attention ranging over the globe and across centuries. Polynesia, it is true, was his haven from the commercialism and rampant technological proliferation he believed to be ravaging the modern world. But his writings abound in reminiscences about and criticisms of his native America and of Europe, where he had served in World War I first with the British Infantry and later as an aviator with the Escadrille Lafayette.

His turning to Polynesia, however, was not a rejection of his American heritage. In work after work he was to extol the Iowa of his youth. I.ong after he had settled in Tahiti, he asserted: "All my roots are still ... in the prairie country of the Middle West." 4 And instead of denouncing American backwoods philistinism as so many other Midwestern authors had done, Hall would complain: "Remote villages and rural communities have lost their identity, and their peace and charm have been sacrificed to that worst of abominations, the automobile." 5 In fact, he sought in the South Seas the features of his boyhood home in Colfax, Iowa, that he most treasured-serenity, smallness of scale, slowness of change, and a closeness to nature. His principal complaint against industry and commerce was that, in their cancerous growth after the first world war, they were destroying the most valuable qualities of communities like Colfax throughout the United States.

Despite such complaints and despite his attacks on war in The Far Lands and A Word for His Sponsor, it might seem glib to proclaim Hall a precursor of the ecology movement or of the pacifism and the communes of the late 1960s and 1970s. He disliked fads and no doubt would have been amused by the silliness and offended by the excesses which have characterized these phenomena. Yet, more than most of his contemporaries, he was appalled by the forces which have distressed so many people recently. And the world he yearned for would probably appeal to a greater number of enlightened persons of the present than the worlds sought by Ezra Pound, T. S. Eliot, William Butler Yeats, D. H. Lawrence, Ernest Hemingway, William Faulkner, or LouisFerdinand Céline-a random but representative list of writers prominent when Hall was producing his best work.

True, by expatriating himself and by evoking the virtues of a vanished preindustrial rural America, Hall shared the tendency Edmund Wilson noted of writers in the 1920s to take refuge from the "perplexities and oppressions" about them by "retreating into a fantasy land" which was usually an idealization of a contemporary region remote

4 My Island Home: An Autobiography (Boston: Atlantic-Little, Brown, 1952), p. 326.

5 Under a Thatched Roof (Boston: Houghton Mifflin, 1942), p. 80. 
from the centers of power or of a bygone era. ${ }^{6}$ But Hall's Polynesia and his turn-of-the-century Iowa, unlike Lawrence's Mexico, Eliot's pious old England, Pound's Provence and Italy, Yeats's Byzantium, and Hemingway's bull ring and Africa-violent or authoritarian places all -were peacefulness and brotherhood epitomized. Both locales came to represent for him values he held to be essential for the psychic wellbeing of mankind. Those values served Hall himself well. Not merely did he retain his sanity in a world he perceived as going mad; he also preserved his sense of humor, his amiable disposition, and, except for a period in the wake of the second world war, his optimism. Indeed, Hall's timeliness (and perhaps timelessness) lies in his refusal to concede that the things he esteemed were irrevocably lost and in his repeated suggestion that in even the worst of times they could be preserved in an individual here and in an isolated community there and that such preservation provided hope for the regeneration of a world defiled by greed and slaughter.

Few of us, of course, read an author simply because he expresses timely sentiments or even provocative ones. We demand that he write persuasively, distinctively, or entertainingly. The last of these Hall could nearly always do whether working with or without Nordhoffhence his popularity. But in the Nordhoff and Hall romances much that is most valuable in Hall gets obscured. Of his longer works of fiction, Doctor Dogbody's Leg, a series of tall-tales narrated by an eighteenth-century English naval surgeon, is an amusing tour de force. Lost Island-a touching account of a South Sea island about to be destroyed to make way for an American military installation-is a small thing done well. The Far Lands-a story set in Polynesian prehistory about a peace-loving tribe's efforts to discover a haven in the vast Pacific-is a large thing done less well. But in his lengthier fictional efforts, without Nordhoff to restrain him, Hall tended to become diffuse and too overtly didactic. Furthermore, his characters are apt to be static or ill-defined. As for his poetry, few are likely to reject the judgment of Hall's friend and editor, Ellery Sedgwick, that most of it is pleasant in an old-fashioned way but is lacking in distinction.?

Where Hall is both distinctive and in complete control of his material is in his essays and sketches. There he fuses tone, form, and style perfectly with his themes. There, too, he succeeds in converting his own appealing personality into an effective persona-tolerant, inquiring, modest yet knowledgeable, idiosyncratic but sensible.

6 "T. S. Eliot and the Church of England," in The Shores of Light (New York: Farrar, Straus, 1952), pp. 438-41.

7 "James Norman Hall," Atlantic, 88 (September 1951):21. 
Of the four volumes of these short works, Under a Thatched Roof, first published in 1942, contains many of the finest and is certainly the most varied in its offerings. We cannot examine all twenty of its offerings here; but, by noting the main thrust of several representative selections, we can show some of Hall's principal concerns as well as the breadth of his interests.

The book begins with "A Word for the Essayist," a paean to those old-fashioned authors who have kept the essay alive in an age of less traditional and more utilitarian forms such as the editorial and the article. It is not surprising that Hall, who since the first world war had been expressing his discomfort with the ever-accelerating pace of life that industry and technology were foisting upon mankind, should have praised the essay for being a bulwark against the ravages of modernity. It is a bit startling, however, to find this native of Colfax, resident of Tahiti, and lifelong hater of cities asserting that essayists are indispensable to society because in times of crisis "they somehow hold fast to urbanity." It is even more jarring when this extoller of primitive life in the South Seas proceeds to proclaim: "When urbanity decays, civilization suffers and decays with it" (p.6).

Yet, for all his adoration of Polynesia, Hall had never been an unequivocal primitivist. If he loved simple islanders, he also doted on authors who were anything but simple-Cervantes, Chaucer, Lamb, and Conrad. His tastes in music inclined more toward the nineteenthcentury symphony than toward savage chants. And the Anglophilia which had blazed from the pages of his first book, Kitchener's Mob, which had flickered throughout his subsequent works, and which glows forth in some of the later selections in Under a Thatched Roof hardly betokens a man for whom "civilization" was a pejorative word. It was not an antipathy toward civilization that had driven Hall from the Western world to the South Pacific. It was, rather, his aversion to a new barbarism which he believed rampant industrialism and commerce were engendering in Europe and America. Furthermore, for Hall, as for Thomas Jefferson, urbanity was by no means contingent upon urbanization. Indeed, for him the two were almost antithetical. In fact the point of this essay is that a truly urbane author must be at odds with the tenor of modern life, which is overwhelmingly city life. Hall contends that such an author will find that eighteenth-century relic, the essay, more congenial than its twentieth-century offspring,

8 Page 9 in the previously cited edition of Under a Thatched Roof. Subsequent quotations are from this edition, and the page numbers are identified in the text in parentheses. 
the article and editorial. Is it astonishing then that Hall should have preferred a South Sea island to New York and Los Angeles?

In "The Scribbling Mania" Hall examines the compulsion writers as a group have for putting words on paper. He rejects Arthur Machen's contention that the source of this urge is a longing to escape from the horrors of life. Life, Hall insists, is not all that terrible. Furthermore, writing itself can be an agonizing experience. He then touches upon a point he had treated extensively in an article entitled "Too Many Books"9_that too many people in the modern world feel compelled to write. Thus, Hall is alarmed to find proliferation, the beast that technology has loosed upon the globe, afflicting even his own profession. Yet, for all his misgivings, he is resigned to enduring the consequent deluge of drivel on the grounds that unpromising writers sometimes later do valuable work. Hall's resignation was sustained, no doubt, by his recollection of the many rejections his own writings had elicited before he was to achieve even a minimal success.

In "A Small Dissenting Voice" Hall, after proclaiming his own attachment to bygone days, says he fears that "there are no past-minded men any more in America" (p. 78). He is especially disturbed by the manner in which links that unite generations have been broken in the United States.

$\mathrm{He}$ is also troubled by the despoliation of nature, and it does not take him long to direct special scorn at the offspring of industry he loathed above all others, the automobile, which he blamed for having destroyed the identity as well as the "charm and peace" of "remote villages and rural communities" (p. 80). At the conclusion of the essay, however, he makes it clear that his major objection to industrialism is not its materialism per se but the giddy pace of life it engenders. When change becomes too rapid, he suggests, both society and individuals suffer. And, in his final words, he asserts that in the United States the rate of change has passed the danger point.

Comment on this essay seems almost superfluous. Its central theme is so integral to Hall's philosophy that it is at least a peripheral element in just about everything he wrote. The only uncharacteristic feature is the unremitting severity of its tone. A parenthetical note at the conclusion goes far toward accounting for that severity-(New York City, 1928). By that year Hall's fortunes had not yet taken much of an upward turn. As for New York, Hall, who disliked cities in general, had a particularly intense antipathy toward that behemoth among American metropolises.

9 Atlantic, 150 (October 1932):458-60. 
In fact, in the next essay, "The Spirit of Place," he singles out New York for special contumely. In Chicago on the elevated railway Hall has known "the silence of a vastness of presence that says 'I am!" He has experienced a similar presence in Kansas City and Denver. But the huge city on the Hudson River-a city where "one is conscious of no mighty influence superior to the works of man"-is a paradigm of the sterility and lack of cohesion of the modern world (p. 88).

In "A Neglected Art" Hall praises idling and upbraids Henry Ford, who epitomized all that Hall disliked about the twentieth century. After castigating Ford for having said that there is no place in civilization for the idler, Hall points out that our nation is suffering from the disastrous effects of industry's rampant growth while "leisure is becoming a wasted raw material" (p. 137). The bane of the United States, he asserts, is that it contains so few "professors" of the art of leisure. In fact, the only ones of the first rank he can identify are Robert Frost, Henry David Thoreau, and Walt Whitman. He sees the source of the contagion not as some unique flaw in the American character but as the Western notion that all scientific ideas must be put to practical use. Indeed, he regards the father of most of our present ills as none other than Sir Francis Bacon.

The main idea here Hall had been expressing as far back as the early 1920s. But perhaps nowhere else does he focus so sharply upon Western civilization's compulsion to act under the aegis of scientific progress regardless of how destructive the actions may be. For him, rationalists like Ford and Bacon are the true madmen: driven creatures who, in their pursuit of knowledge and technological innovation. trample upon everything in nature and society that makes life agreeable. To make matters worse, these men insist upon inducting all of humanity into their legions of seekers and doers. Thus they have turned most of Europe and America into vast armies of frenzied automatons. It is no wonder, therefore, that he was convinced that contemplative persons such as himself had to seek refuge in whatever byways they could find: only there could they preserve their identities and keep alive values essential to the spiritual well-being of mankind.

Hall, anything but a fool, realized that the principal objection most people would have to the simple contemplative life he extolled is that it would quickly pall. The solution he proposes to the problem of boredom in "The State of Being Bored" is characteristic-submission. Unlike acedia-an utter despair curable only by death-boredom is, he contends, a transitory malady. It will resist, however, all deliberate attempts to dispel it. The best we can do is to prepare for our at- 
tacks with fortitude and to endure them. This essay, no less than those denouncing rampant industrialization, challenges Western man's belief that the proper response to every problem is to resort to some kind of purposeful activity. The fortitude that Hall recommends has none of the blustering assertiveness we associate with Theodore Roosevelt. It is more akin to the heroic acquiescence of the Stoics.

The next selection makes a perfect companion piece to its predecessor. In "Happiness" Hall maintains that bliss, no less than boredom, can well up within us spontaneously. There seems to be this difference: whereas boredom can strike any place under just about any circumstances, Hall reports that he had never experienced one of his gratuitous spells of blessedness in a city. What is more, these visitations, as Hall calls them, usually have descended upon him during periods of inactivity and amid natural surroundings back in lowa or in Tahiti. In these two works Hall says, in effect: let us not fight our psyches. Let us drift along with them because they have their own rhythms and offer rewards which can more than compensate for whatever vexations they bring us. We should resign ourselves to their grimmer moods because such moods will pass of their own accord. But if we remain receptive they will reward us with exaltations of a kind we could never will into being. Yet we must aid our psyches a bit. Being a part of nature, they are apt to malfunction in those places which mankind has erected in its misguided war upon nature.

One final point must be made about "Happiness." Although in it Hall describes a mental state that savors of mysticism, he insists that his visitations are "definitely concerned with this good earth" and then maintains that he would experience them more often if possible because he could "wish for no heaven save this one that we have" (p. 161). This is not an appropriate place for a lengthy discussion of Hall's religious opinions. Yet a far more cursory summary of this essay than the one we have presented here should make it apparent that Hall's temperament was reverential. It should be equally apparent that, in his veneration of those benign forces he felt to be governing nature and the soul of man, he owed more to the pantheism of Wordsworth and the Transcendentalism of Thoreau, two of his favorite authors, than to the Protestant theology he had been exposed to in his youth. For Hall, nature was not tainted by original sin, only by Western man's defilement of it in pursuit of "progress." He believed that for the person receptive to the promptings of his own soul and to the bounty of nature, paradise was not lost-only camouflaged.

"Trains" is a hymn to Hall's favorite method of transportation. And because hymns must be sung and cannot be paraphrased, we cannot 
hope to convey its character without quoting it in its entirety, an obvious impossibility. We must explain, though, why Hall should have exempted the railroad alone among the products of technology from his disapproval. His explanation is that, unlike other machines, the steam locomotive seems human. It breathes and has moods like a man or woman. A deeper reason, however, seems to be that the railroad was inextricably entwined with Hall's memories of his boyhood in Iowa.

The essay also contains one of Hall's most explicit statements about the ambivalence of his attitude toward Colfax (here called Prairie Hills). After confessing to a yearning to leave the place as a child, he says: "Now that I look back on it from sufficient distance, I would not have had that boyhood, nor the town where it was spent, changed in any particular" (p. 194). There is, of course, a poignancy to the paradox here of a man looking back longingly at his boyhood self who had yearned to do what the man had done-leave home. To be sure, Hall in a sense never left rural Iowa because he bore it in his memory throughout his life and regained many of its most cherished qualities in the South Seas. Yet neither memory nor replacement could efface his sense of loss as the following passage about the cry of a train whistle on the prairie reveals: "I can hear it, even on this island in the mid-Pacific, and a kind of melancholy seizes me as though it were the last train we are ever to see or hear, on its last journey-into the past" (p. 199).

It may seem anticlimactic to have ended such a book with a light essay that, in addition to recounting Hall's inability to emulate Anthony Trollope's work schedule, disparages James Joyce's Ulysses. Yet, whereas England embodied many of the political and cultural values Hall admired, Joyce represented the literary values he most disliked. And it was in his aesthetic preferences that Hall diverged most acutely from his major literary contemporaries. After all, few writers of consequence have been enamored of the political and economic contours of the twentieth century. And Hall was hardly unique in preferring a bygone era to the present or in favoring some less developed area of the globe over industrialized Europe and America (although the import of his preferences set him well apart from the main stream). But however much authors like Pound, Eliot, Yeats, Lawrence, and Jeffers may have loathed the modern world, they were avid in pursuit of modernity in their own art. This oft-noted blend of literary radicalism with conservative or reactionary politics has been one of the more bizarre incongruities of early and mid-twentieth-century intellectual life. It is a blend that Hall eschewed. The obscure, the perverse, the strident 
repelled him on paper as they repelled him in a person or a society. Moreover, he perceived rampant experimentalism in literature, like technological proliferation, as an assault on stability, simplicity, and continuity-qualities he regarded as essential to the health of individuals and nations. Thus, if Hall was correct, twentieth-century aesthetics have been as misguided as twentieth-century politics.

It is appropriate that most of these short nonfiction pieces, like those in the other collections of Hall's essays and sketches, should have appeared initially in periodicals, because they are specimens of journalism in the best sense of that often debased term. They are an intelligent, literate man's comments on the world about him, but comments designed "to resist obsessive concern with the here and now." Unfortunately there seems to be an a priori assumption, at least in this country, that such offerings become out-of-date after a few spins of the globe.

Then, too, since the essayist addresses himself far less obliquely to his subject than either the poet or novelist does, we are less inclined to read him, whatever his merits, if we feel we are unlikely to care for what he says. Thus even that nonpareil of journalists, that master iconoclast, H. L. Mencken, suffered a precipitous decline in prestige and popularity during the 1930s when readers who had formerly been delighted by his attacks on the "great unwashed" and the "booboiesie" found his writings at best beside the point despite their wit and their verbal acrobatics.

The time may have arrived, however, for us to begin turning to Hall, the essayist. His objections to progress and bigness-objections which must have seemed quaint during his lifetime and downright perverse during the forward-and-upward years of the Kennedy and Johnson administrations-foreshadowed recent calls for zero population growth, a slowdown in industrial expansion, and for modes of living more in harmony with nature. His insistence upon the values of reverie, moreover, presaged the current fascination with various forms of meditation. And surely his belief that certain unspoiled areas of the planet should be kept unspoiled should appeal to members of the Sierra Club. Even his doting on the music of Dvorák no longer seems misguided, as a glance at recent programs of major symphony orchestras and at record reviews in music magazines will confirm.

Hall's idiosyncratic traditionalism in his art as well as in his philosophy could serve as a much-needed corrective to the faddishness that has characterized too many of the trends he anticipated. His humor and common sense, furthermore, are in refreshing contrast to the acerbity and hysteria that have marred so much public discourse in our 
day. Then, too, his essays have a virtue woefully lacking in many recent magazine offerings dealing with similar subjects: they are entertaining.

Hall does not harangue us. Neither does he offer us panaceas. Indeed, he would have been horrified if a substantial number of his readers had emulated him by emigrating to Tahiti-just as horrified as his hero, Thoreau, would have been if all the residents of Concord had built shacks in the environs of Walden Pond. But Hall-a more tolerant, resigned and less self-righteous man than Thoreau-probably either would have made the best of things or would have moved quietly on to another island. And afterwards he would have written an essay about the incident-sad, faintly hopeful, and touched with humor as well as with wit. Hall was no early incarnation of William F. Buckley with a self-appointed mission to stand in the roadway of history and exclaim, "Halt!" He chose, instead, to sit in the shade by the roadside and urge those passers-by not too hurried to listen to slow down and ask themselves whether they really wanted to go where the road was leading them. 


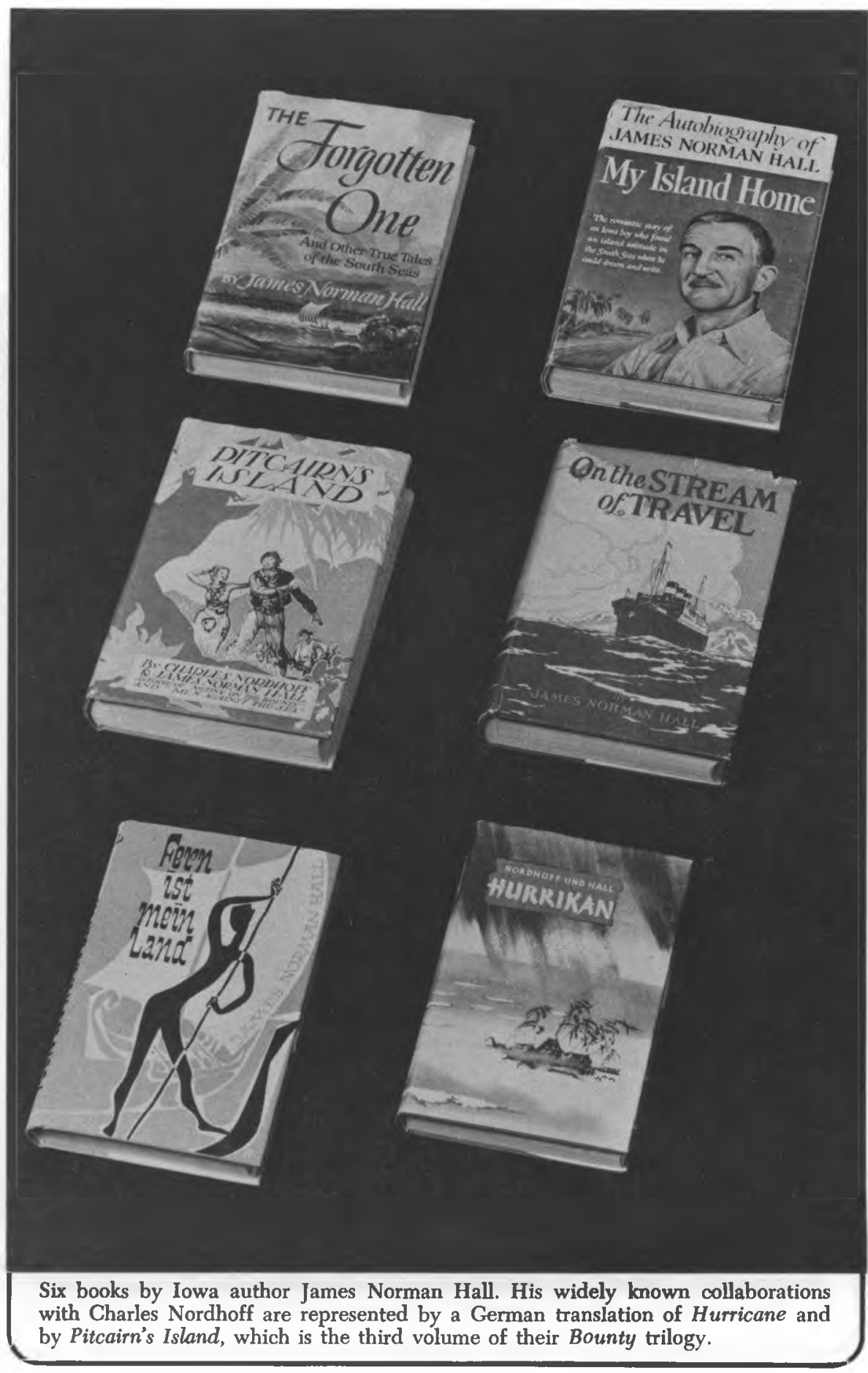




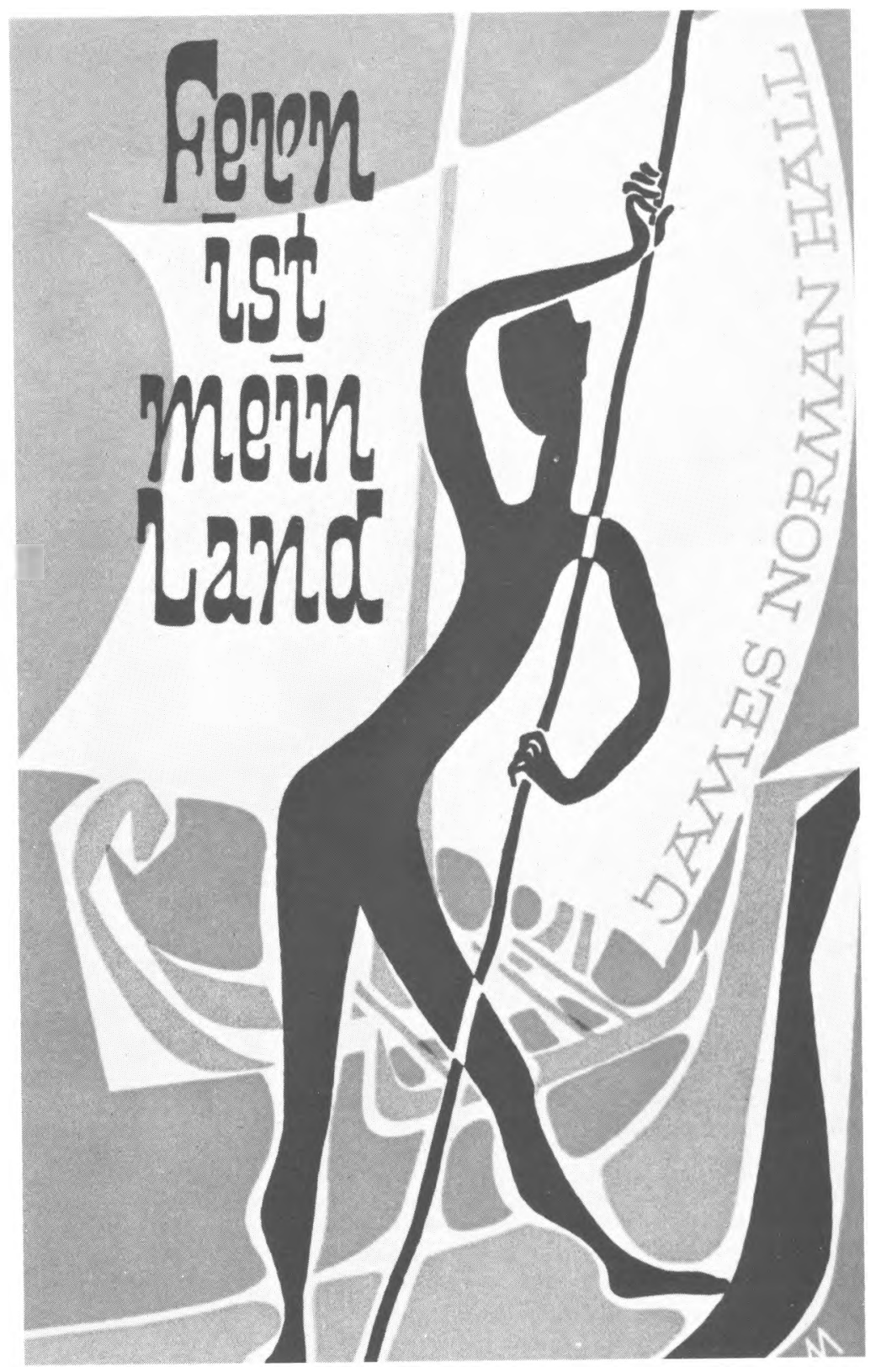

